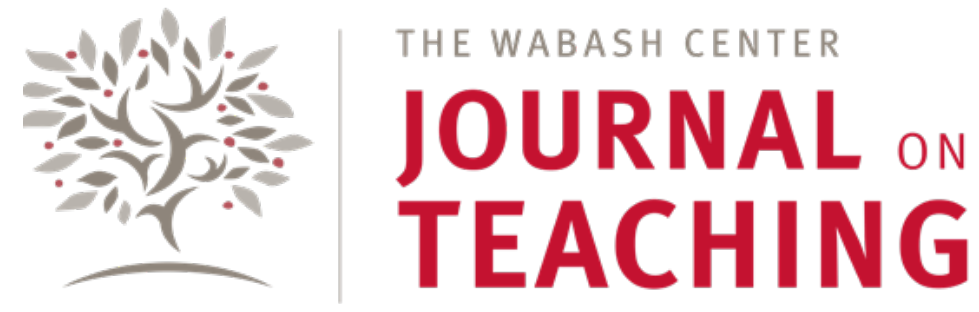

F O R U M

\title{
James Cone: Notes on a Critical Theologian
}

\author{
Adam Clark \\ Xavier University, Cincinnati
}

\begin{abstract}
This short essay reflects on James Cone's transformational impact as a teacher inside the classroom and through his voluminous writings. This is one of several short essays presented by recent students at a public forum at Union Theological Seminary after his death in 2018.
\end{abstract}

\author{
KEYWORDS \\ James Cone, black theology, theology, pedagogy, interpreter
}

It's rare to be asked to speak about Cone as a teacher rather than as a theologian or radical intellectual. To think of Cone as a classroom teacher exclusively seems far too limiting. Cone was one of those rare figures who pioneered an academic discourse, initiating new ways of thinking and seeing Christian faith. His teaching transformed and transcended the classroom, impacting the church, society, and world.

There are many things about Cone that made him a great teacher, but if I had to isolate one, it was his profound capacity for truth-telling-uncomfortable truth-telling. So much of graduate education is obsessed with cognitive truths, "feel good" declarations are espoused by the American church, but Cone struck a dissonant truth that was visceral. The truths he spoke were not soothing or designed to calm and reassure; they were unsettling and challenging truths, ones that disrupted and overturned racial hierarchies and social conventions. Like Malcolm X, Cone was known to "make it plain" and "tell it like it is." Cornel West identifies this as "black prophetic fire"-a spirit within the black radical tradition carved by figures who exposed lies, celebrated the good, and bore witness. James Cone was the incarnation of this spirit.

Listening to Cone narrate the story of black suffering and joy was liberating. For those of us who had the great fortune of studying with Cone, there was an additional benefit; not only was he a brilliant articulator of subjugated truths but he also showed us how to leverage black anger and rage as resources for truth-telling. In a bourgeois society that routinely penalizes open expressions of anger from black bodies, witnessing Cone name "whiteness" and "white religion" as enemies of Christian faith and human community was empowering. It gave us new language for coming to grips with absurdity of black suffering and opened new horizons of possibility for thinking faith in novel ways. How Cone spoke about race theologically was almost as important as what he said. When Cone spoke about race, he didn't whisper or worry if whites would be offended, he spoke with a piercing sense of theological determination, straight from his gut. Cone wasn't just heard, he was felt. Cone's capacity to access his gut as a resource for truth gave students the courage to access theirs.

Cone conceived of theology as an ongoing conversation. To be a student of the tradition, one must learn its interlocuters, its sources and norms as well as its exclusions, silences, and limitations. The problem, he explained, was that whites didn't regard blacks and other marginalized people as serious conversation partners. They were the excluded Others, fit to be 
recipients of the tradition but not agents in its construction. Europe, he warned, had no monopoly on the meaning of the faith. As a corrective, Cone centered black people in theological discourse as producers of knowledge. His deep dive into the history and culture of black people to elevate them as equal to Europeans revolutionized the category of "human experience" within theology. Blackness became the new creative standpoint for engaging and reimagining Christian faith.

As fierce a critic as Cone was, what thrilled Cone more than critique was creativity and innovation. No matter how sharp your critique of classical theological perspectives, Cone would push you to include your constructive contribution to the dialogue. From someone who forged black theology into an academic discipline, this makes sense. It's difficult for most students to appreciate how unlikely the institutionalization of black theology at predominately white seminaries and universities was. Black power advocates were considered anti-white, anti-American, and anti-Christian, their rhetoric was considered hate speech (remember the reaction to Obama's former pastor, Jeremiah Wright). American Christianity emphasized themes of love, reconciliation, and forgiveness when it comes to race relations. To not only mix a militant Black Power movement with a love-inspired Christianity but to claim, as Cone did, that the message of black power was identical to Christ liberating activity in North America did not seem like a defensible theological position at elite institutions. Yet Cone, with intellectual sophistication, was not only able to prosecute academic theologians ignoring race, he also initiated a new discourse in Christian faith that identified black history as a primary realm of meaning and purpose, a site of divine activity. God, for Cone, is active, in a liberating and goal-orientated way in black history in culture. Within black theological discourse, black history and culture are sacred texts and can be regarded as sources for knowing God in the same way white Christians regard the Bible. Along with radical clergy in the National Conference of Black Christians, Cone started to evolve black theology with early publications and debates with Charles Long, Carleton Lee, Gayraud Wilmore, Major Jones, J. Deotis Roberts, and his brother Cecil Cone. As Cone embraced and learned from his critics, he emerged as the Father of Black Theology, providing the majority of its early literature and dominant methods of inquiry, revalorizing its sources and reframing traditional confessional categories. The inclusion of blackness into the realm of theology was not just an "add on" to assimilate into a received theological tradition but radical call for the re-making of the discipline itself. Shortly after the institutionalization of black theology, the study of black history and culture, black religion and theology became a significant part of many mainstream seminaries and departments of religion around the country.

As radical a thinker as Cone was, he was a fairly traditional pedagogue. His introductory classes were lecture style, in which he was a commanding and charismatic presence; his upper-level courses were seminar style with student presentations. Much of what made him effective in both arenas was unique to his persona. What I learned from him most was how he approached the intellectual formation of students and the discipline of theology.

\section{Finding Your Own Theological Voice}

For Cone, finding one's theological voice is "the pearl of great price." When I arrived at Union, I assumed Cone would be interested in manufacturing "black theologians," similar to the way Henry Ford manufactured Model T cars. To my surprise, he scoffed at the idea, "What I think about theology is very well known. . . be yourself!" he insisted (1998). The pathway to discovering one's voice was in conversation with others.

Cone wrote extensively about his own struggles in coming to voice. In 1967, teaching at Adrian College, a rebellion broke out in nearby Detroit. As a recent doctoral graduate, he was well acquainted with the theologies of Barth, Tillich, and other European theologians yet he was woefully ill-equipped to say anything meaningful about the black struggle for justice. What the hell does systematic theology have to say about the pain and sufferings of my people, he wondered? The few blacks who had formal degrees in theology mimicked white theologians so Cone had no professional role models. It wasn't until he encountered the teachings of Malcolm X that his consciousness became revolutionized. "Malcolm taught me how to make theology black and to never again despise my African origins. . . I was transformed from a Negro theologian to a Black theologian" Cone recalled (1999b, xxi). "The revolution that Malcolm X created in my theological consciousness meant that I could no longer make peace with the intellectual mediocrity in which I had been trained. The more I trusted my experience, the more new thoughts about God and theology whirled around in my head-so fast I could hardly contain my excitement" (1999a, 251). "Blackness opened my eyes to see African American history and culture as one of the most insightful sources for knowing about God since the Bible was declared a canon" (1999a, 251). "My newfound blackness impelled me to write, to let the world know that a new voice had arrived on the theological scene" $(2018,8)$. 
As a classroom teacher, Cone was interested in forming creative interpreters, not robots or clones. Each student, he believed, has a unique path of discernment. For Cone, it was through the Civil Rights and Black Power movement, for others in Union's ecosystem, it was Marxist and socialist movements, womanist/feminist movements, LGBTQ movements, and/or eco-justice movements. During the process of discernment, Cone encouraged students to affirm the truths of their experience and critique the limitations of established theological perspectives, even his own.

\section{Critical Interpreters of Faith}

The second strategy l've learned from Cone is to cultivate students to be critical interpreters of the faith. For many newcomers, the questions within theological discourse seem settled and fixed. Cone was clear that theological questions and constructs don't drop from the sky, they emerged from a complex matrix of ideas and conditions of interpreters from times past. Cone was fond of saying, "The Bible tells us to love God with all your heart, all your soul, and all your mind." Theology is loving God with your whole mind. He often added, "The black church does a good job with the first two, but not as good a job with the last one" (1998).

Loving God with your whole mind is to engage the task of interpretation. Instead of naively accepting the received tradition and prioritizing its ecclesial agenda (baptism, communion, spiritual gifts, end-time prophesies, miracles, and so forth) Cone claimed that the best way to determine whether an issue is theologically significant is to see if it makes us re-examine the relationship between God and humanity. White supremacy, for example, is theologically significant because it results in the inability to see the imago dei in the Other. This reframing of the theological task opens new horizons of possibility for identifying and discussing faith issues in classroom contexts.

In addition to being critical interpreters of the faith, Cone pushed us to interpret the interpreters. That is to say, to place ourselves inside the socio-political milieu of a theologian and try to understand why a specific question or controversy was so important to them. Also, we should try to determine why a specific response to a theologian seemed to settle an issue for that age even though it may not settle it for our age. In examining new theological perspectives, Cone prodded us to ask, "What are the dominant assumptions of this age? What are its tests of religious authority? What questions are we choosing not to ask?" He challenged students to be attentive to how questions change from age to age. It is this form of creative inquiry and robust exchange that helped form students as critical interpreters.

\section{Epistemic Humility}

In teaching theology, it's important to remind students that theology is human language about God, not God-language about humans. Cone was allergic to absolutism. All human understanding is historically and linguistically conditioned. Therefore Christian God-language is always an approximation, not a complete grasping of God in and of Godself. The irony of the theological task is that we are applying human language and constructs to a God who constantly exceeds our grasp. The proper response to this process is deep humility.

In the context of a classroom, it's important to remind students that God-talk is an imaginative act, more art than science. Greek categories are not timeless truths and western metaphysics have a hard time capturing the transformative activity of a God in solidarity with the poor. Identifying our human constructs too closely with God is idolatry. So we shouldn't be overly confident about our language. Religious language is always metaphorical so there's no one way to talk about God. "God is Black, God is Red, God is Rice. . . are all anthropomorphic ways of speaking about God” Cone stated (1993, 392). In this way, "God chooses what is foolish to shame the wise, God chose what is weak in the world to shame the strong" ( 1 Corinthians 1:27). The vocation of theology is unlike other disciplines in a liberal arts curriculum; we should not just blindly promote university mission with their rhetorical claims of promoting good citizenship or teaching students to be good members of communities we know to be unjust. The vocation of a theologian it is to be a thorn in the flesh of all that oppresses and causes misery. In this way, theologians are in the academy but not of the academy. 


\section{ADDITIONAL CONTRIBUTIONS TO THE FORUM ON DR. JAMES CONE}

Editor. 2020. "Introduction to the Forum on Dr. James H. Cone as Teacher and Mentor." The Wabash Center Journal on Teaching 1(2): 79-80. https://doi.org/10.31046/wabashcenter.v1i2.1501.

\section{BIBLIOGRAPHY}

Cone, James H. 1993. “Black Theology and Third World Theologies.” In Black Theology: A Documentary History, Volume Two: 1980-1992, edited by James H Cone and Gayraud Wilmore, 388-98. Maryknoll, NY: Orbis.

Cone, James H. 1998. “THEO 103 Lecture.” New York, NY: Union Theological Seminary.

Cone, James H. 1999a. “Looking Back, Going Forward: Black Theology as Public Theology.” In Black Faith and Public Talk: Critical Essays on James H. Cone's Black Theology \& Black Power, edited by Dwight N. Hopkins, 246-259. Maryknoll, NY: Orbis.

Cone, James H. 1999b. Risks of Faith: The Emergence of a Black Theology of Liberation, 1968-1998. Boston, MA: Beacon Press.

Cone, James H. 2018. Said I Wasn't Gonna Tell Nobody: The Making of a Black Theologian. Maryknoll, NY: Orbis Books.

\section{ABOUT THE AUTHOR}

Adam Clark is a former doctoral student of James Cone and current Associate Professor of Theology at Xavier University in Cincinnati, Ohio. He writes and teaches courses on Black Theology and Faith and Justice. His forthcoming publications focus on shaping the future of black theology in the twenty-first century. 